NOTICE: this is the author's version of a work that was accepted for publication in Marine Pollution Bulletin. Changes resulting from the publishing process, such as peer review, editing, corrections, structural formatting, and other quality control mechanisms may not be reflected in this document. Changes may have been made to this work since it was submitted for publication. A definitive version was subsequently published in Marine Pollution Bulletin, Vol. 73, No. 1 (2013). DOI: 10.1016/j.marpolbul.2013.05.036 


\title{
Metal concentrations in sediments from tourist beaches of Miri City, Sarawak, Malaysia (Borneo Island)
}

\author{
R. Nagarajan ${ }^{1}$, M. P. Jonathan ${ }^{2 \dagger}$, P. D. Roy ${ }^{3}$, L. Wai-Hwa ${ }^{1}$, \\ M.V. Prasanna ${ }^{1}$, S.K. Sarkar ${ }^{4}$ and M. Navarrete-López ${ }^{5}$ \\ ${ }^{1}$ Department of Applied Geology, School of Engineering and Science, Curtin University, \\ CDT 250, Miri, 98009, Sarawak, Malaysia. \\ ${ }^{2}$ Centro Interdisciplinario de Investigaciones y Estudios sobre Medio Ambiente y Desarrollo \\ (CIIEMAD), Instituto Politécnico Nacional (IPN), \\ Calle 30 de Junio de 1520, Barrio la Laguna Ticomán, \\ Del. Gustavo A. Madero, C.P.07340, México DF., México. \\ ${ }^{3}$ Instituto de Geología, Universidad Nacional Autónoma de México (UNAM), \\ Ciudad Universitaria C.P. 04510, Coyoacan, México DF., México. \\ ${ }^{4}$ Department of Marine Science, University of Calcutta, \\ 35 Ballygunge Circular Road, Calcutta - 700 019, India. \\ ${ }^{5}$ Escuela Nacional de Ciencias Biológicas, Laboratorio Central de Instrumentación, \\ Instituto Politécnico Nacional (IPN), Prol. de Manuel M Carpio y Plan de Ayala, \\ Col. Sto. Tomas, Del. Miguel Hidalgo, C.P.11340, México DF., México. \\ ${ }^{\dagger}$ Corresponding author. Tel.: +52 5557296000 Ext: 52707, 52708; fax: +52 5557296000 \\ E-mail address: mpjonathan7@yahoo.com
}

Keywords: beach sediments, partially leachable trace metals, contamination, Miri, Sarawak, Malaysia.

Revised Manuscript submitted to Baseline Section, Marine Pollution Bulletin (May, 2013). 


\begin{abstract}
43 sediment samples were collected from the beaches of Miri City, Sarawak, Malaysia to identify the enrichment of partially leached trace metals (PLTMs) from six different tourist beaches. The samples were analyzed for PLTMs Fe, Mn, Cr, Co, Cu, Ni, $\mathrm{Pb}, \mathrm{Sr}$ and $\mathrm{Zn}$. The concentration pattern suggest that the southern side of the study area is enriched with higher concentration of Fe (1821-6097 $\left.\mu \mathrm{g} \mathrm{g}^{-1}\right), \mathrm{Mn}\left(11.57-90.22 \mu \mathrm{g} \mathrm{g}^{-1}\right), \mathrm{Cr}$ (51.50-311 $\left.\mu \mathrm{g} \mathrm{g}^{-1}\right)$, Ni (18-51 $\left.\mu \mathrm{g} \mathrm{g}^{-1}\right), \mathrm{Pb}\left(8.81-84.05 \mu \mathrm{g} \mathrm{g}^{-1}\right), \operatorname{Sr}\left(25.95-140.49 \mu \mathrm{g} \mathrm{g}^{-1}\right)$ and $\mathrm{Zn}\left(12.46-35.04 \mu \mathrm{g} \mathrm{g}^{-1}\right)$. Compared to the eco-toxicological values, $\mathrm{Cr}>$ Effects range low (ERL), Lowest effect level (LEL), Severe effect level (SEL); Cu > Unpolluted sediments, ERL, LEL; $\mathrm{Pb}>$ Unpolluted sediments and $\mathrm{Ni}>$ ERL and LEL. Comparative results with other regions indicate that $\mathrm{Co}, \mathrm{Cr}, \mathrm{Cu}, \mathrm{Ni}$ and $\mathrm{Zn}$ are higher, indicating an external input rather than natural process.
\end{abstract}


Miri city is located in the northern part of Sarawak, Malaysia, which also forms part of the Borneo Island. The coastal region is enriched with fossil fuels, mainly petroleum and the city is also the birth place of oil industry for Malaysia during 1900s. The other principal industries which dominate this region are the fast growing timber processing and palm oil production. The Baram river drains in the northern part of the study area and the average discharge is $1590 \mathrm{~m}^{3} / \mathrm{s}$ (Sandal, 1996) and, likewise the Miri river criss-crosses the city and drains in the South China Sea. The beaches in this region are often vulnerable to oil pollution due to the presence of numerous oil platforms in the offshore region as well as the cargo vessels in this part. Previous studies also indicate that the drainage effluents which drain and accumulate into the South China Sea is stamped with huge residential properties (Ho and Kumar, 2011; Ho and Quan, 2012). The movement of cargo vessels, transportation of industrial products (timber $\operatorname{logs}$ ), and the numerous coastal developments have documented to higher level of contamination in the beaches of Miri (Minton and Peter, 2009). The annual mean rainfall in the study area varied from 2247 to $3499 \mathrm{~mm}$ in 1981 1990 (avg. $2715 \mathrm{~mm}$ ), 2228 to $3265 \mathrm{~mm}$ for the period of 1991-2000 (avg. $2682 \mathrm{~mm}$ ) and 2516 to $3267 \mathrm{~mm}$ through 2001-2010 (avg. 2916) respectively (Jabatan Meterologi, Malaysia, 2009). The beaches in most part of this region is dominated by sandy texture with open stands of Casuarina equisetifolia, coarse grasses and shallow swamps running parallel to the coast in most places.

Recently, Miri is also focusing on development of tourism in this region and is also occupied by natural parks, exotic coral reefs, beaches and during 2011 nearly 3,795,373 visitors has visited Sarawak State alone (Sarawak Tourism Quick Facts, 2011). The city is also dominated by narrow beaches for nearly $25 \mathrm{~km}$ in the southern part of the Baram delta region facing the South China Sea, where the waves are relatively small and low in energy 
predominantly in micro-tidal range (Lambiase et al., 2002). Geologically, tertiary sandstone reservoirs dominate the region (Johnson et al., 1989).

The present study attempts in documenting a baseline data related to the concentration pattern of partially leached trace metals (PLTMs) in sediments from the tourist beaches due to the growing tourist activities in the Miri City.

Sediment sample collection in the inter-tidal region of the beaches was done during 2011 based on the tourist population history visiting the particular locations. Surface sediment samples $(\mathrm{N}=43)$ were collected from 6 tourist beaches, viz Lutong Beach (LB) $(\mathrm{n}=9)$, Park Everly Beach (PE) $(\mathrm{n}=4)$, Tanjong Lobang Beach (TL) $(\mathrm{n}=8)$, Esplanade Beach (EP) $(n=9)$, Hawaii Beach $(\mathrm{HB})(\mathrm{n}=8)$ and Bungai Beach $(\mathrm{BU})(\mathrm{n}=5)$ respectively (Fig. 1a-f). The modified EPA 3051A method was used with autoclave digestion in determining the concentration of PLTMS of Fe, $\mathrm{Mn}, \mathrm{Co}, \mathrm{Cr}, \mathrm{Cu}, \mathrm{Ni}, \mathrm{Pb}, \mathrm{Sr}$ and Zn (Navarrete-López et al., 2012). 0.5 g of sediment sample was digested for nearly 40 minutes with $\mathrm{HNO}_{3}+\mathrm{HCl}$ (9:3 ratio) acid mixture in a PFA [Poly(tetrafluoroethylene)] vessel at $119 \pm 1.5^{\circ} \mathrm{C}$ and the final solution was made upto $50 \mathrm{ml}$ after filtration. The solution was directly introduced in the ICP-OES (Varian 720 ES) to measure PLTMs: Fe, Mn, Co, Cu, Ni, Sr, Zn, whereas, Cr, Pb were measured by AASGF (Varian Spectra AA220 G7A110). The reagents used in the present analysis were of analytical grade (J.T. Baker). The precision of the analysis was done using Standard Reference Material (SRM No.691029) Loam Soil B (soil sample) and it was run after every $5^{\text {th }}$ samples and the accuracy level was within the acceptable limits. Statistica (Version 8) was used to generate the correlation matrix for the PLTMs in order to identify the relationship between the metals. 
The concentration pattern of PLMTs along the beaches of Miri City is presented in figure 2a-i. Likewise, in order to verify the existence of common source involving the PLTMs, correlation matrix results are presented in the text version and the comparison of the analyzed elements with that of eco-toxicological values are presented in table 1 respectively.

General distribution pattern of PLTMs indicate that mostly the beaches in the southern part $(\mathrm{EB}, \mathrm{HB}, \mathrm{BB})$ is enriched by majority of metals (except $\mathrm{Co}, \mathrm{Cu}$ ) which might be due to the long shore currents transporting the materials to the southern part as this coastal region is actively eroded throughout the year (Cheong, 2000; James, 1984). The above inference is also supported by the huge cargo ship traffic, Miri River (draining in the coastal region), smaller channels $(>15)$ that brings in domestic, industrial and agricultural effluents into the coastal beaches. Our results also indicate that the concentration pattern of PLTMs in the study area varies depending on the nature of input through the local channels that drains in the region. The concentration pattern of PLTMs indicates higher values of Fe in EP (avg. $3030 \mu \mathrm{g} \mathrm{g}^{-1}$ ), HB (avg. $4408 \mu \mathrm{g} \mathrm{g}^{-1}$ ) and BB (avg. $3625 \mu \mathrm{g} \mathrm{g}^{-1}$ ) and Mn in EP (avg. 26.25 $\mu \mathrm{g} \mathrm{g}^{-1}$ ), HB (avg. $52.94 \mu \mathrm{g} \mathrm{g}^{-1}$ ) and BB (avg. $34.89 \mu \mathrm{g} \mathrm{g}^{-1}$ ) respectively. The use $\mathrm{Fe}$ in construction, transportation industries indicates that it is easily in contact with either fresh or marine water and as it is chemically reactive, the process of corrosion is very high, which in turn accumulates in the sediments. Moreover, naturally Fe leaches from the clastic sediments also contributing $\mathrm{Fe}$ content to beach sediments which is common phenomenon of the beaches of Miri particularly, in Tanjong Labung and Bungai beaches. The presence of electrical, pigment, ceramics and fertilizer plants indicates the use of Mn in higher level and the discharges from these will also increase the concentration level (eg. Kabata-Pendia and Pendias, 2001). 
PLTM Co indicates higher values in TL (avg. $37.46 \mu \mathrm{g} \mathrm{g}^{-1}$ ) and EP (avg. $20.40 \mu \mathrm{g}$ $\mathrm{g}^{-1}$ ) than other beaches. Likewise, $\mathrm{Cr}$ indicate that all the beaches [avg. (in $\mu \mathrm{g} \mathrm{g}^{-1}$ ) LB: 85.33; PE: 100.25; TL: 140.13; EP: 82.83; HB: 253.75; BB: 95.00] in this region are above the permissible limits (except ERM). The higher concentration of the above metals is mainly due to the electroplating, antifouling paints (in ships), leather tanning, varnishes, wood (use of preservatives), automobile industries, magnetic \& sludges and the deforested agricultural fields in the upland region (eg. Alloway 1995; Maata and Singh 2008; Maján et al., 2001; Nicholson et al., 2003; Nriagu and Pacyna 1988). PLTM Ni indicates higher values in the beaches of LB (avg. $18.78 \mu \mathrm{g} \mathrm{g}^{-1}$ ), PB (avg. $\left.23.50 \mu \mathrm{g} \mathrm{g}^{-1}\right)$, EP $\left(33.89 \mu \mathrm{g} \mathrm{g}^{-1}\right)$, HB $\left(40.63 \mu \mathrm{g} \mathrm{g}^{-1}\right)$ and $\mathrm{BB}\left(30.80 \mu \mathrm{g} \mathrm{g}^{-1}\right)$ than ERL and LEL values. Higher values of PLTM Pb are also reported from LB (avg. 19.67), HB (avg. $18.61 \mu \mathrm{g} \mathrm{g}^{-1}$ ), which are well below the eco-toxicological values. Some peak values of 84 and $42 \mu \mathrm{g} \mathrm{g}^{-1}$ (in EP \& BB) PLTM $\mathrm{Pb}$ is mainly due to the local vehicular traffic, effluents and also due to the proximity of the sampling point. PLTM Zn in the study area varies depending on site, as high (PE: 28.31; EB: 27.50; BB: $24.00 \mu \mathrm{g} \mathrm{g}^{-1}$ ) and low values (LB: 17.93; TL: 19.89; HB: $\left.18.66 \mu \mathrm{g} \mathrm{g}^{-1}\right)$ are observed in the beach sediments and they are within the permissible limits. Anyhow, the anthropogenic input of $\mathrm{Zn}$ cannot be neglected as it is used in various industries for alloys, chemical production and in steel components. With reference to PLTM Sr, the southern region dominates with higher averages in EB $\left(91.25 \mu \mathrm{g} \mathrm{g}^{-1}\right), \mathrm{HB}$ (51.06 $\left.\mu \mathrm{g} \mathrm{g}^{-1}\right)$, BB $\left(84.80 \mu \mathrm{g} \mathrm{g}^{-1}\right)$ and even though there is no specific values for comparison the use of $\mathrm{Sr}$ in paints, glass, television sets cannot be ruled out. The higher concentrations could also be due to the mobile nature of $\mathrm{Sr}$ in the deforested region and is also leached down from the calcareous beds which are subsequently transported by the smaller channels (eg. Brent and Harding, 1995). The rapid development of Miri city 
compared with steady increase of population result in enrichment of both inorganic and organic pollutants which are detrimental for the living organisms. The carbonate rich regions could have the easily mobile elements absorbed, and subsequently the bioavailability to organisms also increases naturally (eg. Belzile et al., 1989; Li et al., 2001). The concentration pattern of the PLTMs is also closely related to the hydrodynamic condition of the coastal region due to the southern currents.

The comparative results for the beach sediments with that of other selected beaches and bay regions around the World suggest a four-fold increase of $\mathrm{Co}, \mathrm{Cr}, \mathrm{Cu}$; two-fold increase of $\mathrm{Ni}, \mathrm{Pb}$ and $\mathrm{Zn}$ in the study area indicating that mostly the elements are anthropogenic due to the increased human activities in the region (Table 1). This is also due to the non-proper planning and uncontrolled discharge of contaminated industrial sewage and domestic sludge into the drains which gets accumulated in time and then drains into the open ocean during monsoon seasons.

The above inference is very well supported by their individual association Fe $v s \mathrm{Mn}$ $\left(r^{2}=0.90\right)$, its scavenging capacity which is observed by the correlation of Fe $v s \mathrm{Ni}\left(r^{2}=\right.$ $0.79), \mathrm{Mn} v s \mathrm{Ni}\left(r^{2}=0.76\right)$ and $\mathrm{Sr} v s \mathrm{Fe}\left(r^{2}=0.48\right), \mathrm{Mn}\left(r^{2}=0.42, \mathrm{Ni}\left(r^{2}=0.44\right)\right.$ indicating that they are mainly from external input (eg. Gao et al., 2002; Jain and Sharma 2006). The association of $\mathrm{Sr}$ could be related to natural and anthropogenic source which is dominated by the geologically calcareous rocks in this region. The separate association of $\mathrm{Cu} v s \mathrm{Zn}\left(r^{2}\right.$ $=0.72$ ) clearly suggests that they are from external sources.

Even though various control measures are adopted, the human activities still impact the coastal beach quality and there is an urgent need to protect the beaches of Miri in Sarawak, Malaysia before it goes out of control. 
Acknowledgements: First Author RN wishes to express his gratefulness to the Curtin Sarawak Research Institute Academic Grant (CSRI2011/Grants/01) for financial assistance. Authors MPJ and PDR wish to express their thanks to SNI, CONACyT, México. Special thanks to Mr. Isidro Garrido Enrique, ENCB, IPN, Mexico for his help during the analysis in AAS and ICP. MPJ wishes to express his thanks to IPN (COFAA, EDI), México. This article is the $72^{\text {nd }}$ contribution from Earth System Science Group (ESSG), Chennai, India. 


\section{References}

Abu-Hilal, A.H., 1987. Distribution of trace elements in near shore surface sediments from the Jordan Gulf of Aqaba (Red Sea). Mar. Poll. Bull., 18(4), 190-193.

Alloway, B.J., 1995. Heavy metals in soils, Blackie Academic and Professional, UK, pp.363.

Belzile, N., Lecomte P., Tessier, A., 1989. Testing readsorption of trace elements during partial chemical extractions of bottom sediments. Environ Sci Tech., 23, 1015-1020.

Brent, G.F., Harding, M.D., 1995. Surfactant coatings for the stabilization of barium peroxide and lead dioxide in pyrotechnic compositions. Prop. Expl. Pyro. 20, 300303.

Cheong, Y.P., 2000. Sand body character of the modern Baram Delta: Implications for petroleum reservoir models in northwest Borneo. Unpublished M.Sc Thesis, Universiti Brunei Darussalam, 53 pp.

Fukushima, K., Saino, T., Kodama, Y., 1992. Trace metal contamination in Tokyo Bay, Japan. Sci. Total Env., 125, 373-389.

James, D.M.D., 1984. The geology and hydrocarbon resources of Negara Brunei Darussalam, Bandar Seri Begawan: Muzium Brunei, 169 pp.

Johnson, H. D., Kuud, T., Dundang, A., 1989. Sedimentology and reservoir geology of the Betty field, Baram Delta province, offshore Sarawak, NW Borneo. Geol. Soc. Malaysia Bull., 25, 119-161.

Jonathan, M.P., Ram-Mohan, V., 2003. Heavy Metals in Sediments of the Inner shelf off Gulf of Mannar, South East Coast of India. Mar. Poll. Bull., 46 (2), 263-268.

Jonathan, M.P., Roy, P.D., Thangadurai, N., Srinivasalu, S., Rodríguez-Espinosa, P.F., Sarkar, S.K., Lakshumanan, C., Navarrete-López, M., Muñoz-Sevilla, N.P., 2011. 
Metal concentrations in water and sediments from tourist beaches of Acapulco, Mexico. Mar. Poll. Bull., 62, 845-850.

Gao, X., Chen, Z., Zhang, N., Xu, S., Chen, L., 2002. Heavy metals and phosphorous in tidal flat sediments of the Yangtze estuary. J. Geogra. Sci., 12 (4), 472-478.

Ho, C., Kumar, D.J., 2011. Water quality from a mixed land-use catchment in Miri, Sarawak. World Acad. Sci. Eng \& Tech., 60, 598-602.

Ho, C., Quan, C.B., 2012. Runoff and pollution loading from a residential catchment in Miri, Sarawak. World Acad. Sci. Eng \& Tech., 71, 1635-1638.

Kabata-Pendias, A., Pendias, H., 2001. Trace elements in soil and plants, 3rd edn., CRC, Boca Raton, FL. pp.413.

Lambiase, J. J., Abdul-Rahim, A. A. B., Peng, C. Y., 2002. Facies distribution and sedimentary processes on the modern Baram delta: implications for the reservoir sandstones of NW Borneo. Mar. Pet. Geol., 19, 69-78.

Li, X. D., Shen, Z., Wai, O. W. H., \& Li, Y-S. 2001. Chemical forms of Pb, Zn and Cu in the sediment profiles of the Pearl River estuary. Mar. Poll. Bull., 42, 215-223.

Long, E.R., Mac Donald, D.D., Smith, S.L., Calder, F.D., 1995. Incidence of adverse biological effects within ranges of chemical concentrations in marine and estuarine sediments. Env. Manag. 19, 81-97.

Maján, G.Y., Kozák, M., Püspöki, Z., McIntosch, R., Mikó, L., 2001. Environmental geological examination of chromium contamination in Eastern Hungar. Env. Geochem. Health, 23, 229-233.

Malaysia Drainage and Irrigation Department, 1991. Coastal processes, feasibility study and detailed design of coastal protection works from Miri to Kuala Baram (Sarawak), vol. 3, pp. 4-1:4-22. 
Maata, M., Singh, S., 2008. Heavy Metal Pollution in Suva Harbor Sediments, Fiji. Env. Chem. Lett., 6, 113-118.

Minton, G., Peter, C., 2009. Sarawak Dolphin Project Year end final report, July 2009. p.45.

Navarrete-López, M., Jonathan, M.P., Rodríguez-Espinosa, P.F., Salgado-Galeana, J.A., 2012. Autoclave decomposition method for metals in soils and sediments. Env. Monit. Assess., 184 (4), 2285-2293.

Nicholson, F. A., Smith S. R., Alloway B. J., Carlton-Smith C., Chambers B. J. 2003. An inventory of heavy metals inputs to agricultural soils in England and Wales. Sci. Total Env., 311, 205-219.

Nriagu, J.O., Pacyna, J., 1988. Quantitative assessment of worldwide contamination of air, water and soil by trace metals. Nature, 333, 134-139.

Razi-Idris, W.M., Abdul-Rahim, S., Ali-Rahman, Z., Lihan, T., Hashim, A., Mohd-Yusuf, S.N., 2009. Geochemical composition of beach sediment in Langkawi Island, Kedah, Malaysia. Sains Malayssiana, 38 (3), 313-320.

Salomons, W., Förstner, U., 1984. Metals in Hydrocycle. Springer, Berlin Heidelberg New York, pp 63-98.

Sarawak Tourism Quick Facts (2011). Information Booklet. Ministry of Tourism Sarawak (Publs.), 22p.

Santhiya, G., Lakshumanan, C., Jonathan, M.P., Roy, P.D., Navarrete-López, M., Srinivasalu, S., Uma-Maheswari, B., Krishnakumar, P., 2011. Metal enrichment in beach sediments from Chennai Metropolis, SE coast of India. Mar. Poll. Bull., 62 (11), 2537-2542. 
Sandal, S.T., 1996. The geology and hydrocarbon resources of Negara Brunei Darussalam, Bandar Seri Begawan: Syabas, p.243.

Shengfa, L., Yanguang, L., Gang, Y., Shuqing, Q., Chaoxin, L., Zhiwei, Z., Xuefa, S., 2012. Distribution of major and trace elements in surface sediments of Hangzhou Bay in China. Acta. Oceanol. Sin., 31 (4), 89-100.

Tokunaga, T.K., Wan, J., Firestone, M.K., Hazen, T.C., Olson, K.R., Herman, D.J., Sutton, S.R., Lanzirotti, A., 2003. In situ reduction of chromium (VI) in heavily contaminated soils through organic carbon amendment. J. Env. Qual., 32, 16411649.

United States Environmental Protection Agency (USEPA),, 2001. The role of screeninglevel risk assessments and refining contaminants of concern in Baseline ecological risk assessments, Publication 9345 0-14, EPA 540/F-01/14, June, 2001. 


\section{List of tables}

Table 1 Comparison of metal concentrations with that of eco-toxicological values used for evaluating aquatic environments. 


\section{List of figures}

Figure 1a-f Study area map with sampling locations in beaches of Miri, Sarawak, Malaysia. Figures a-f is the expanded vision of sample collection from the six different beaches.

Figure 2a-i Distribution pattern of acid leachable metals (ALMs) in six different beach sediments of Miri, Sarawak, Malaysia. 


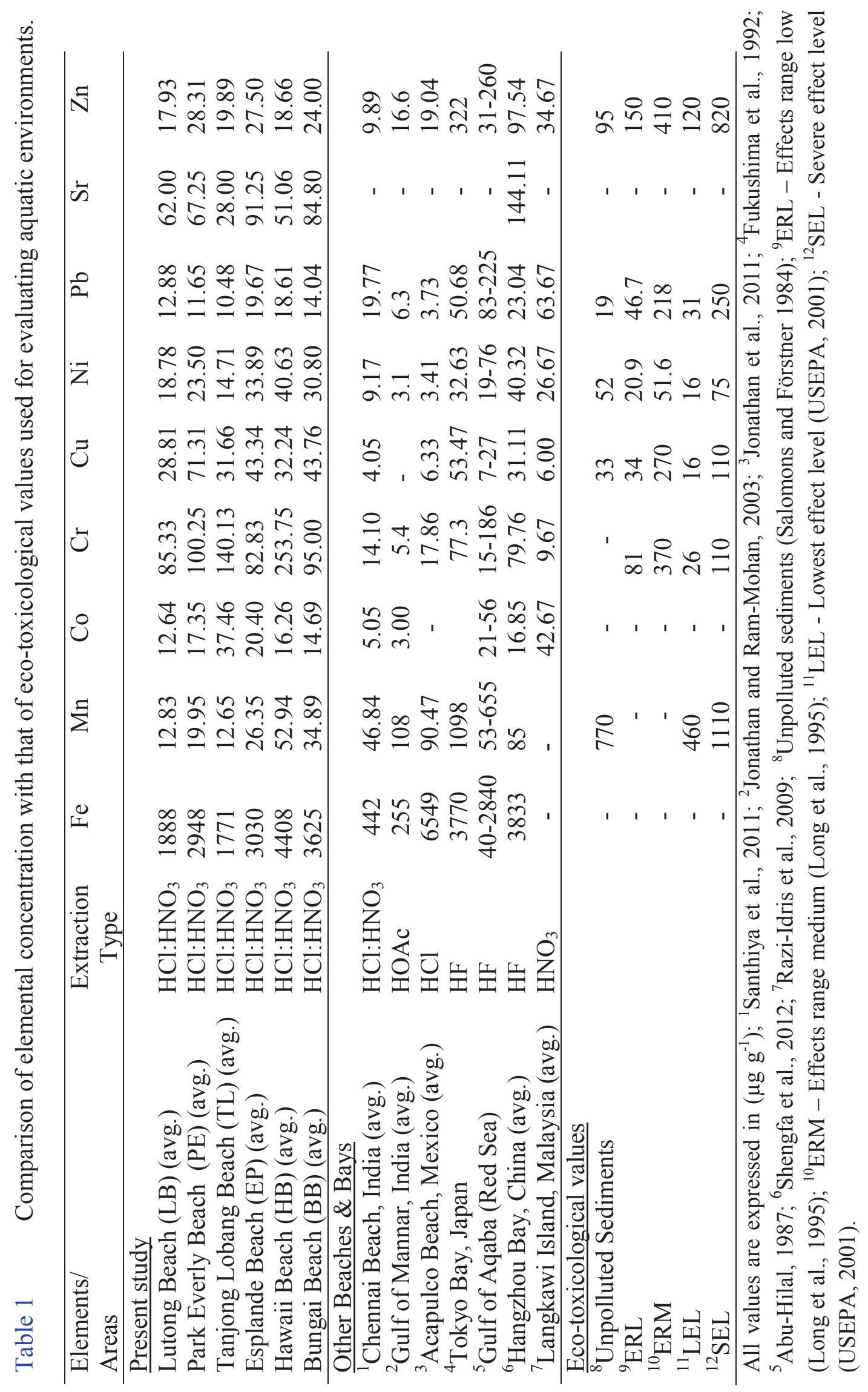



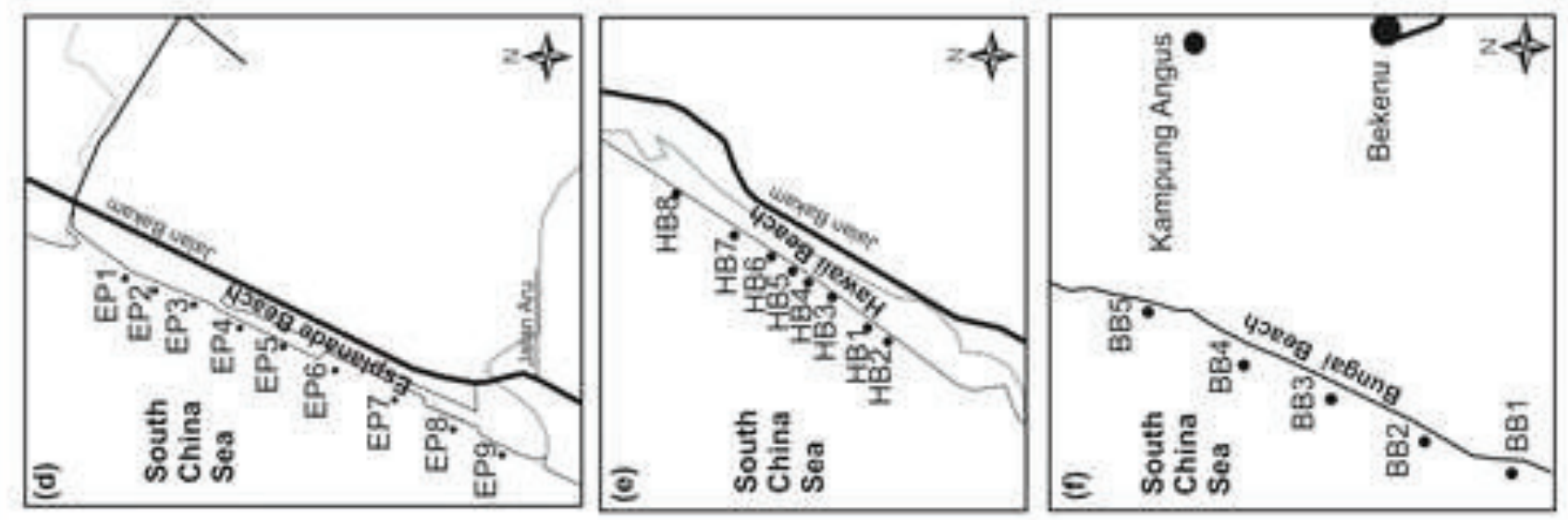

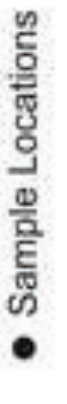
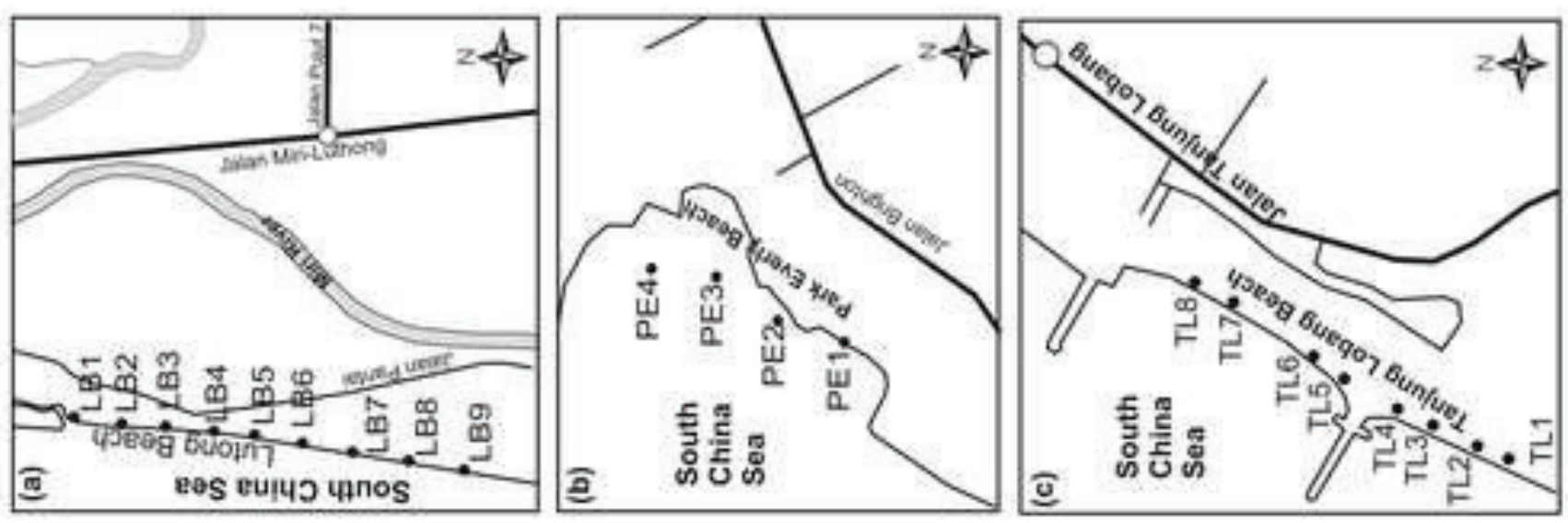

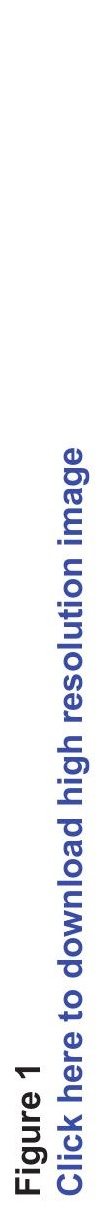

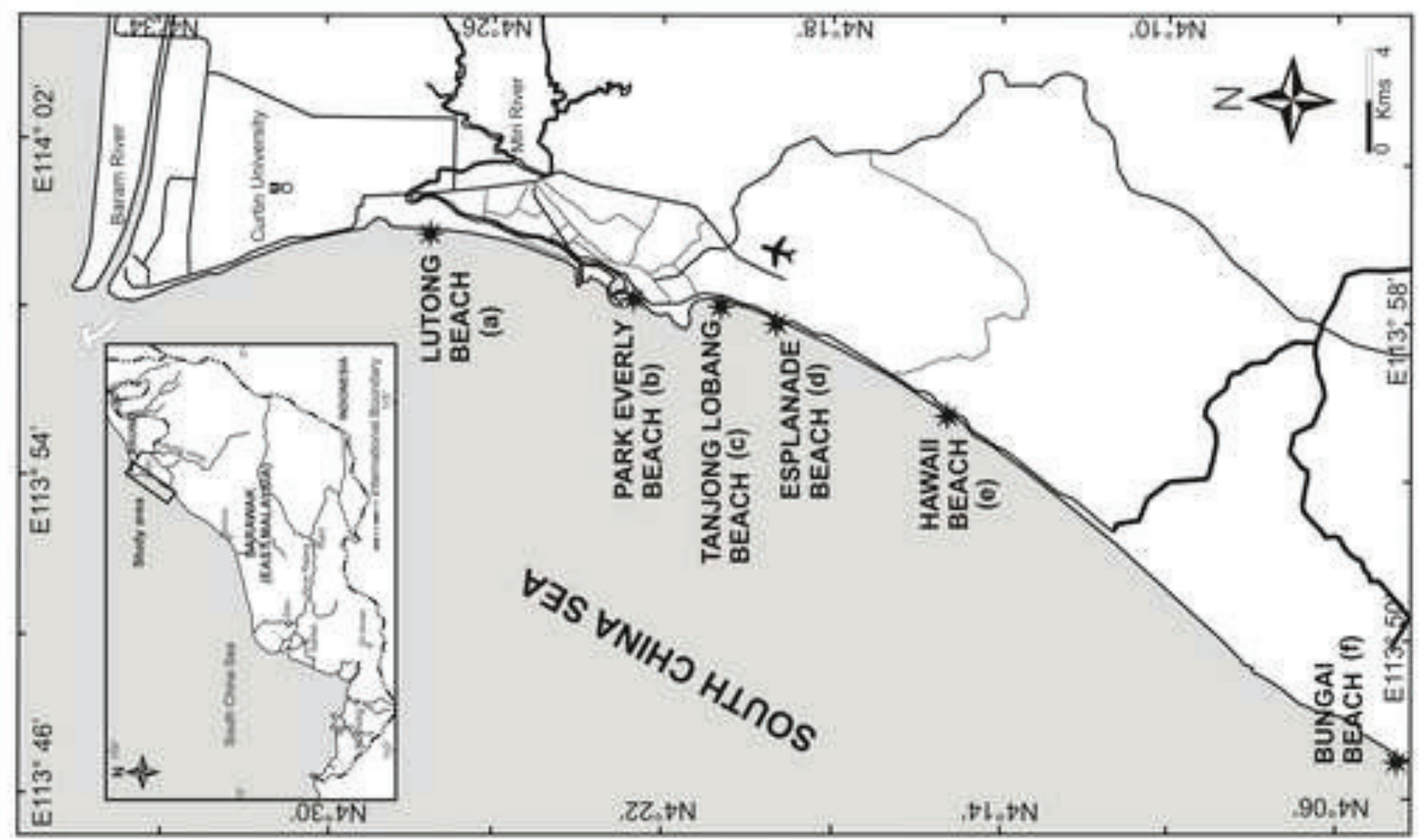




\section{Figure 2}

Click here to download high resolution image
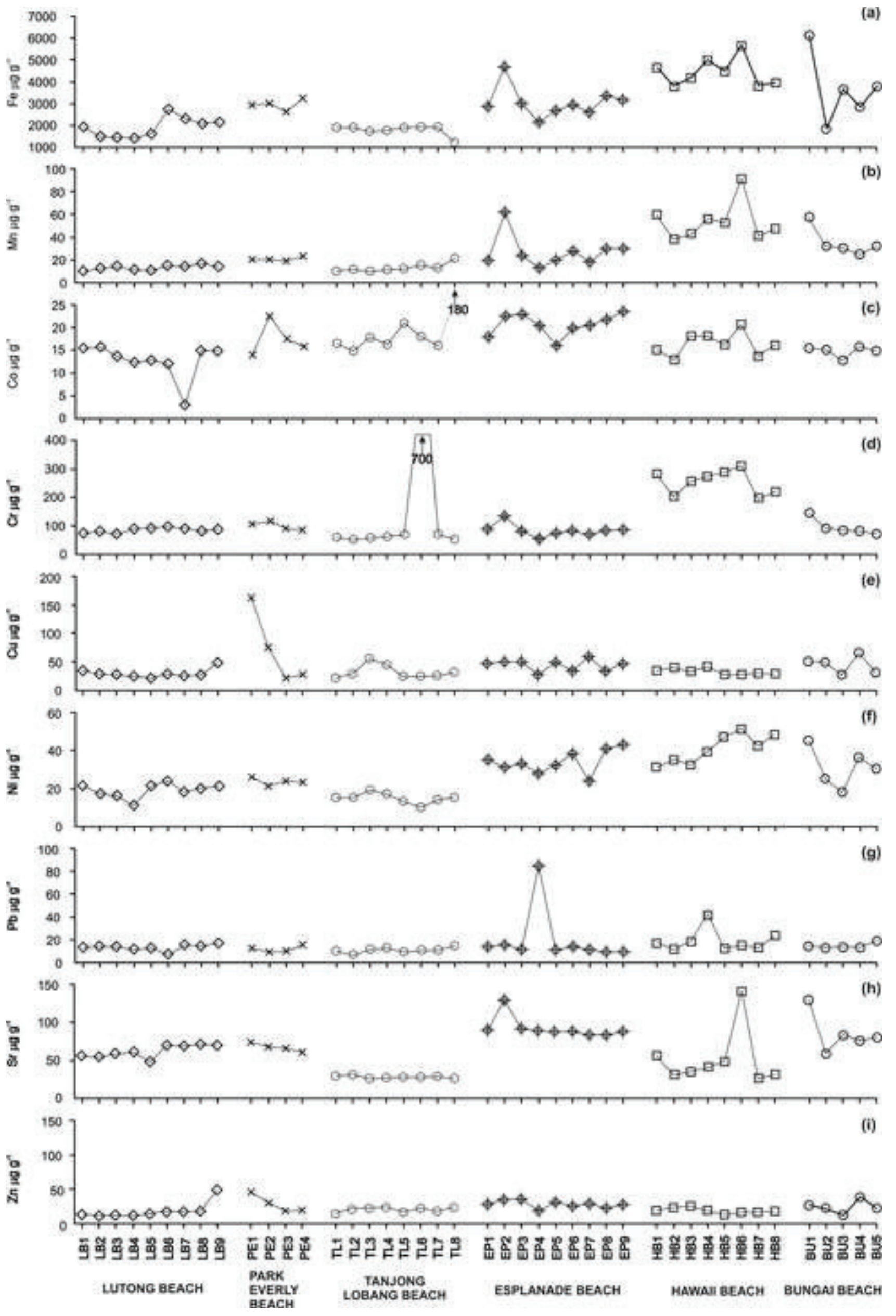